\title{
Plant sterols induce intestinal tumor formation in gender-related manner in ApcMin mice
}

\author{
Maija Marttinen ${ }^{1 *}$, Anne-Maria Pajari ${ }^{1}$, Essi Päivärinta', Markus Storvik², Mikael Niku ${ }^{3}$, Tanja Nurmi ${ }^{4}$, Vieno Piironen ${ }^{4}$, \\ Marja Mutanen ${ }^{1}$
}

From Metabolism, diet and disease

Washington, DC, USA. 29-31 May 2012

\section{Background}

Plant sterols are plant derived dietary compounds that are structurally similar to cholesterol. Plant sterols reduce cholesterol absorption, and therefore plant sterol enriched functional foods are designed to lower blood cholesterol level. Reduction of cholesterol absorption increases the level of intraluminal cholesterol, and high intraluminal cholesterol concentration has been associated with enhanced cell proliferation, aberrant crypt formation and tumor formation $[1,2]$. The aim of this study was to investigate, how plant sterols affect intestinal tumorigenesis, sterol composition of the faeces and the intestinal mucosa, and cell signaling in tumor-prone ApcMin mice.

\section{Materials and methods}

The ApcMin mouse is a well-characterized model for studying associations between dietary factors and colon cancer development. ApcMin mice were fed either a high fat, low fiber AIN93-G based control diet $(\mathrm{n}=12)$ or a $0.8 \%$ $(w / w)$ plant sterol enriched diet $(n=12)$ for 9 weeks. Plant sterol esters were added to the diet in plant sterol enriched margarine. At the end the diet period, intestinal adenomas were counted, and samples were collected for sterol, Western blot, and gene expression analyses.

\section{Results}

The number of intestinal tumors increased significantly in plant sterol fed female ApcMin mice (46.8 \pm 6.7$)$ com-

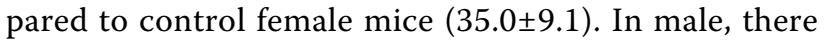
was no difference in the number of tumors between the plant sterol and control group $(41.1 \pm 8.2$ and $36.3 .0 \pm 8.5$, respectively). No difference in the size of intestinal tumors was observed between the experimental groups.

'Department of Food and Environmental Sciences, Division of Nutrition,

University of Helsinki, Helsinki, Finland

Full list of author information is available at the end of the article
The faecal cholesterol concentration increased by 3.4fold after plant sterol feeding. The level of mucosal cholesterol decreased in plant sterol fed male compared to control male $(-18 \%, p=0.01)$ and plant sterol fed female $(-13 \%, \mathrm{p}=0.028)$. There was no difference in the mucosal cholesterol level in female between groups. Plant sterol feeding increased the level of plant sterols in the intestinal mucosa, and in male resulted in 2-fold higher mucosal sitosterol level compared to female. No difference between groups was found in levels of nuclear cyclin D1 or $\beta$-catenin, however, nuclear $\beta$-catenin was increased in plant sterol fed female compared to plant sterol fed male (2.2 \pm 0.2 and $1.3 \pm 0.4$, respectively; $p=0.011)$. Enrichment of regulated genes belonging to the terpenoid backbone synthesis (KEGG pathway database) was detected after plant sterol feeding in female. The upregulated genes of the terpenoid backbone synthesis $(M v k, P m v k$, Idi1) transcribe enzymes of the mevalonate pathway, which produces cholesterol and isoprenoids for the cell.

\section{Conclusions}

Plant sterols accelerated intestinal tumor formation in ApcMin mice, and the effect was mainly seen in female. In female, plant sterol feeding upregulated gene expression of several enzymes in cholesterol biosynthesis. Our study suggests that in tumor initiation plant sterol enriched diet has no effect in male but is harmful in female mice.

\footnotetext{
Acknowledgements

We thank Anna-Maija Lampi for assistance in the sterol analysis. This study was financially supported by the Finnish Graduate School on Applied Biosciences and the Yrjö Jahnsson Foundation.

Author details

Department of Food and Environmental Sciences, Division of Nutrition, University of Helsinki, Helsinki, Finland. ${ }^{2}$ School of Pharmacy, University of Eastern Finland, Kuopio, Finland. ${ }^{3}$ Department of Veterinary Biosciences, University of Helsinki, Helsinki, Finland. ${ }^{4}$ Department of Food and
} 
Environmental Sciences, Division of Food Chemistry, University of Helsinki, Helsinki, Finland.

Published: 1 June 2012

\section{References}

1. Kendall CW, Janezic SA, Friday D, Rao AV: Dietary cholesterol enhances preneoplastic aberrant crypt formation and alters cell proliferation in the murine colon treated with azoxymethane. Nutr Cancer 1992,

17:107-114.

2. Rao AV, Janezic SA, Friday D, Kendall CW: Dietary cholesterol enhances the induction and development of colonic preneoplastic lesions in C57BL/6J and BALB/CJ mice treated with azoxymethane. Cancer Lett 1992, 63:249-257.

doi:10.1186/1753-6561-6-S3-P34

Cite this article as: Marttinen et al:: Plant sterols induce intestinal tumor formation in gender-related manner in ApcMin mice. BMC Proceedings 2012 6(Suppl 3):P34.

\section{Submit your next manuscript to BioMed Central} and take full advantage of:

- Convenient online submission

- Thorough peer review

- No space constraints or color figure charges

- Immediate publication on acceptance

- Inclusion in PubMed, CAS, Scopus and Google Scholar

- Research which is freely available for redistribution

Submit your manuscript at www.biomedcentral.com/submit 